\title{
An improved $\mathrm{NO}_{2}$ retrieval for the GOME-2 satellite instrument
}

\author{
A. Richter, M. Begoin, A. Hilboll, and J. P. Burrows \\ Institute of Environmental Physics, University of Bremen, Otto-Hahn-Allee 1, 28359 Bremen, Germany \\ Received: 23 December 2010 - Published in Atmos. Meas. Tech. Discuss.: 13 January 2011 \\ Revised: 9 June 2011 - Accepted: 14 June 2011 - Published: 22 June 2011
}

\begin{abstract}
Satellite observations of nitrogen dioxide $\left(\mathrm{NO}_{2}\right)$ provide valuable information on both stratospheric and tropospheric composition. Nadir measurements from GOME, SCIAMACHY, OMI, and GOME-2 have been used in many studies on tropospheric $\mathrm{NO}_{2}$ burdens, the importance of different $\mathrm{NO}_{\mathrm{x}}$ emissions sources and their change over time. The observations made by the three GOME-2 instruments will extend the existing data set by more than a decade, and a high quality of the data as well as their good consistency with existing time series is of particular importance.

In this paper, an improved GOME- $2 \mathrm{NO}_{2}$ retrieval is described which reduces the scatter of the individual $\mathrm{NO}_{2}$ columns globally but in particular in the region of the Southern Atlantic Anomaly. This is achieved by using a larger fitting window including more spectral points, and by applying a two step spike removal algorithm in the fit. The new GOME-2 data set is shown to have good consistency with SCIAMACHY $\mathrm{NO}_{2}$ columns. Remaining small differences are shown to be linked to changes in the daily solar irradiance measurements used in both GOME-2 and SCIAMACHY retrievals.

In the large retrieval window, a not previously identified spectral signature was found which is linked to deserts and other regions with bare soil. Inclusion of this empirically derived pseudo cross-section significantly improves the retrievals and potentially provides information on surface properties and desert aerosols.

Using the new GOME-2 $\mathrm{NO}_{2}$ data set, a long-term average of tropospheric columns was computed and high-pass filtered. The resulting map shows evidence for pollution from several additional shipping lanes, not previously identified in satellite observations. This illustrates the excellent signal to noise ratio achievable with the improved GOME-2 retrievals.
\end{abstract}

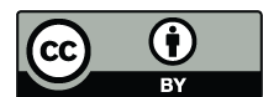

Correspondence to: A. Richter (richter@iup.physik.uni-bremen.de)

\section{Introduction}

Nitrogen dioxide $\left(\mathrm{NO}_{2}\right)$ is an important trace gas in the Earth's atmosphere. In the stratosphere, it is involved in ozone chemistry as a catalyst for ozone destruction and also in the formation of halogen reservoirs such as chlorine nitrate. In the troposphere, nitrogen oxides $\left(\mathrm{NO}_{\mathrm{x}}=\mathrm{NO}+\mathrm{NO}_{2}\right)$ together with volatile organic compounds are key ingredients for ozone formation. By reaction with the hydroxyl radical $(\mathrm{OH}), \mathrm{NO}_{2}$ forms nitric acid $\left(\mathrm{HNO}_{3}\right)$ which leads to acidification of precipitation and in consequence acidifies soils and water bodies with negative impacts on the environment. Via its role in ozone formation, $\mathrm{NO}_{\mathrm{x}}$ is relevant for the Earth's radiation budget. At high concentrations, $\mathrm{NO}_{2}$ can also contribute directly to radiative forcing (Solomon et al., 1999).

Atmospheric nitrogen dioxide can be detected by remote sensing measurements using the strong differential absorption structures of the $\mathrm{NO}_{2}$ molecule in the UV/visible part of the spectrum. Such measurements have been used extensively to monitor $\mathrm{NO}_{2}$ from the ground (e.g. Noxon, 1975; Brewer et al., 1973; Solomon et al., 1987; Van Roozendael et al., 1997; Liley et al., 2000) and from space (e.g. Leue et al., 2001; Richter and Burrows, 2002; Martin et al., 2002; Beirle et al., 2003; Richter et al., 2005; van der A et al., 2006). In particular satellite measurements which provide global coverage are well suited to study the stratospheric and tropospheric $\mathrm{NO}_{2}$ burden and its change over time. To fully exploit the potential of satellite observations, high quality long-term data sets of $\mathrm{NO}_{2}$ are needed, combining measurements from different sensors to one consistent data set.

Space-borne observations of $\mathrm{NO}_{2}$ started with stratospheric measurements from the LIMS (Limb Infrared Monitor of the Stratosphere, Russell III et al., 1984) and SAGE (Stratospheric Aerosol and Gas Experiment, Chu and McCormick 1986) instruments. The first global tropospheric $\mathrm{NO}_{2}$ observations were possible with the Global Ozone Monitoring Experiment (GOME) launched in July 1995 (Burrows et al., 1999). They were continued by the

Published by Copernicus Publications on behalf of the European Geosciences Union. 
Table 1. Overview on settings for the standard and improved $\mathrm{NO}_{2}$ retrieval. Eta is a calibration function representing the polarisation sensitivity of the GOME-2 instrument.

\begin{tabular}{lll}
\hline & Standard & $\mathrm{New}$ \\
\hline fitting window & $425-450 \mathrm{~nm}$ & $425-497 \mathrm{~nm}$ \\
spectral points & 125 & 360 \\
polynomial & 5 coeff. & 3 coeff. \\
Shift \& squeeze & Earth-shine only & Earth-shine only \\
cross-sections & $\mathrm{NO}_{2}, \mathrm{O}_{3}, \mathrm{O}_{4}$, & $\mathrm{NO}_{2}, \mathrm{O}_{3}, \mathrm{O}_{4}$, \\
& $\mathrm{H}_{2} \mathrm{O}, \mathrm{Ring}, \mathrm{Offset}$ & $\mathrm{H}_{2} \mathrm{O}, \mathrm{Ring}$, Offset \\
& & $\mathrm{H}_{2} \mathrm{O}_{\text {liq }}$, Sand, Eta \\
spike correction & $\mathrm{No}$ & Yes \\
\hline
\end{tabular}

Scanning Imaging Spectrometer for Atmospheric Chartography (SCIAMACHY) (Bovensmann et al., 1999), launched on ENVISAT in 2002, and since 2004 by OMI (Ozone Monitoring Instrument) on AURA (Levelt et al., 2006). With the successful launch of the first of a series of three GOME- 2 instruments on MetOp-A in October 2006 (Callies et al., 2000), the foundation was laid for a continuous data set of a total of $25 \mathrm{yr}$ of $\mathrm{NO}_{2}$ measurements from space.

There are several GOME-2 $\mathrm{NO}_{2}$ products available, including the operational EUMETSAT O3MSAF data product (Valks et al., 2011), the TEMIS data product, which was used to investigate the effect of pollution control in China (Mijling et al., 2009), and the IUP Bremen standard GOME-2 data, which were applied to the investigation of ship emissions (Franke et al., 2009) and to the interpretation of atmospheric VOC levels (Vrekoussis et al., 2010).

In this paper, we report on an improved $\mathrm{NO}_{2}$ dataset retrieved from GOME-2 measurements. The focus is on improvements of the first step of the analysis, i.e. the retrieval of slant columns, rather than on refinements on the airmass factors, which are needed to convert the slant columns to vertical columns. To improve the standard retrievals, two steps are taken; first, the spectral range used is extended and second, an explicit removal of spikes in the spectra is applied. It is shown that for the large fitting window, additional terms need to be included in the analysis, which account for the effects of liquid water absorption in clear oceanic regions, residual calibration issues at the edge of the scan, and a signal linked to sand and soil on the surface. The effect of the new retrieval settings is a significant reduction in scatter of the $\mathrm{NO}_{2}$ columns, in particular in the region of the Southern Atlantic Anomaly (SAA). The new $\mathrm{NO}_{2}$ columns are then compared to data retrieved from the SCIAMACHY instrument and very good agreement is found. Finally, as an example for the utility of the improved data set, an average $\mathrm{NO}_{2}$ field is computed over nearly 4 yr of GOME- 2 data, which shows evidence for pollution from several shipping lanes not previously detectable from space.

\section{The GOME-2 standard $\mathrm{NO}_{2}$ product}

The retrieval of atmospheric $\mathrm{NO}_{2}$ amounts from UV/visible measurements from space is based on the application of the Differential Optical Absorption Spectroscopy (DOAS) (Platt 1994). Briefly, molecular absorption cross-sections are fitted to the logarithm of the ratio of a nadir measurement and a direct solar observation without atmospheric absorptions. The resulting fit coefficients are the integrated number of molecules per unit area along the atmospheric light path for each trace gas and are called slant columns. To account for broadband absorption and scattering effects, a low order polynomial is included in the fit as well as a pseudo absorber which corrects for inelastic scattering or Ring effect (Solomon et al., 1987). The slant columns depend on the observation geometry, the position of the sun and also on parameters such as the presence of clouds, aerosol load and surface reflectance. They are therefore converted to vertical columns through division by an airmass factor which is computed with a radiative transfer model and accounts for the average light path through the atmosphere. If tropospheric columns are to be derived, additional steps are needed to remove the stratospheric $\mathrm{NO}_{2}$ contribution.

The baseline of the GOME- $2 \mathrm{NO}_{2}$ retrieval at the University of Bremen is to use the same settings as applied to data from the predecessor instruments GOME and SCIAMACHY as described in previous work (Richter and Burrows, 2002; Richter et al., 2005). These settings have been chosen to provide the best differential $\mathrm{NO}_{2}$ signal which is in the range of $425-450 \mathrm{~nm}$, and the smallest interference by other species and geophysical parameters. They are also limited by instrumental parameters, such as the spectral coverage of the instrument and calibration issues, which affect GOME and SCIAMACHY spectra from $460-500 \mathrm{~nm}$. Any change to these parameters needs to be well justified as it potentially introduces inconsistencies in the long-term data set created from the data of the different instruments. Some details on the settings used are given in Table 1 . The crosssections used are ozone and $\mathrm{NO}_{2}$ at $223 \mathrm{~K}$ measured with the GOME-2 instrument (P. Spietz, private communication, 2005), $\mathrm{O}_{4}$ (Greenblatt et al., 1990), $\mathrm{H}_{2} \mathrm{O}$ (Rothman et al., 2005) and Ring effect (Vountas et al., 1998). It should be noted that the GOME-2 data discussed here are not the operational O3MSAF GOME-2 lv2 products, but rather a scientific dataset retrieved from lv1 data using the University of Bremen DOAS algorithm as described in (Richter and Burrows, 2002). However, the settings of the operational product are very similar to those used here (Valks et al., 2011), and therefore the improvements discussed below will likely be analogue if applied to the operational product.

When comparing $\mathrm{NO}_{2}$ data from the standard GOME-2 product and SCIAMACHY, the good overall agreement is obvious. This is illustrated in Fig. 1, where $\mathrm{NO}_{2}$ columns from both instruments are shown for August 2007. In these graphs, a stratospheric airmass factor was assumed. While 

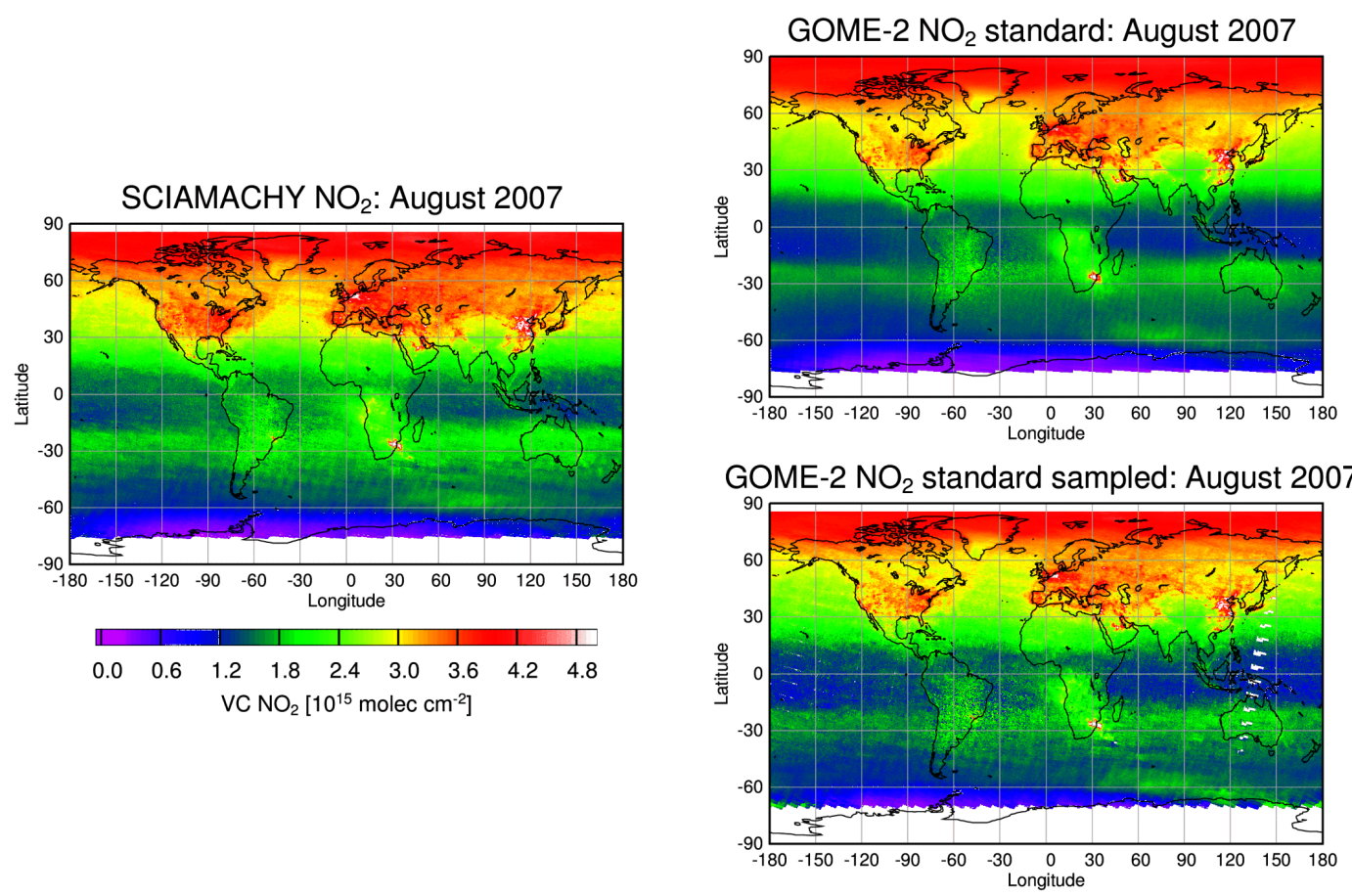

Fig. 1. Comparison of SCIAMACHY (left) and GOME-2 standard product (right) $\mathrm{NO}_{2}$ monthly average for August 2007. A stratospheric airmass factor has been applied and only forward scan pixels with solar zenith angles below $90^{\circ}$ have been used. No cloud screening was applied. In the upper GOME-2 figure, all data are shown, while in the lower figure, only values were used, where a corresponding SCIAMACHY value was available on the same day. As SCIAMACHY data have not been filtered in the same way, some sampling differences still remain.

this is not appropriate for regions affected by tropospheric pollution, it should not impair the comparison. Two versions of the GOME-2 average are shown, one using all the data and another, where only those measurements are used for which there is a corresponding SCIAMACHY observation. This sampling for coincident measurements clearly improves the agreement between the two instruments but reduces the precision of the GOME-2 data, as only part of the measurements can be used. Although there is very good overall consistency, GOME-2 standard evaluation values are lower than SCIAMACHY columns by about $2.0 \times 10^{14} \mathrm{molec}^{-2}$, and also show less spatial detail. On the other hand, the GOME-2 global field is much smoother than in the case of SCIAMACHY data, which show some variability linked to the chess-board pattern of daily measurements, which results from the alternating limb and nadir measurements. Some differences between the two data sets are to be expected; SCIAMACHY has better spatial resolution $\left(30 \times 60 \mathrm{~km}^{2}\right.$ as compared to $40 \times 80 \mathrm{~km}^{2}$ for GOME-2), which results in more structured tropospheric signals. The two instruments also have a difference in overpass time of about $30 \mathrm{~min}$, which can make a difference in stratospheric $\mathrm{NO}_{2}$ amount, in particular at low sun (e.g. Ionov et al., 2008). As GOME-2 is measuring earlier in the morning, stratospheric $\mathrm{NO}_{2}$ columns should be slightly smaller, but the observed differences are larger than expected which will be further discussed in Sect. 5. Locally, the time difference may also be relevant for the tropospheric columns, e.g. when the overpass is close to the rush hour peak.

In order to investigate the random noise of the individual GOME- 2 measurements, data over the clean equatorial $\mathrm{Pa}-$ cific $\left(5^{\circ} \mathrm{S}-5^{\circ} \mathrm{N}, 150-210^{\circ} \mathrm{E}\right)$ have been analysed. In this area, one can assume that the stratospheric $\mathrm{NO}_{2}$ columns are relatively constant over one month, that the tropospheric $\mathrm{NO}_{2}$ burden is small, and that spatial variations over the region can be neglected. Under these assumptions, the spread in GOME-2-retrieved $\mathrm{NO}_{2}$ columns is a measure of the random noise of the measurements. In Fig. 2, the results of this analysis are shown for data from August 2007. As in Fig. 1, a stratospheric airmass factor was applied to correct for the (small) changes in solar zenith angle and the effect of the variable line of sight angle of the observations. The figure also includes the results of the same analysis on SCIAMACHY data, and on the improved data set (discussed later). As can be seen, the distribution of GOME-2 standard retrieval columns is nearly Gaussian with a FWHM of $5.8 \times 10^{14}$ molec $\mathrm{cm}^{-2}$ for the vertical column corresponding to about $1.6 \times 10^{15}$ molec $\mathrm{cm}^{-2}$ for the slant columns. This is larger than the value found for SCIAMACHY $\left(5.0 \times 10^{14} \mathrm{molec}^{-2}\right)$, indicating larger scatter in the GOME-2 data. This result is disappointing, as the GOME-2 instrument was designed for high throughput, and 


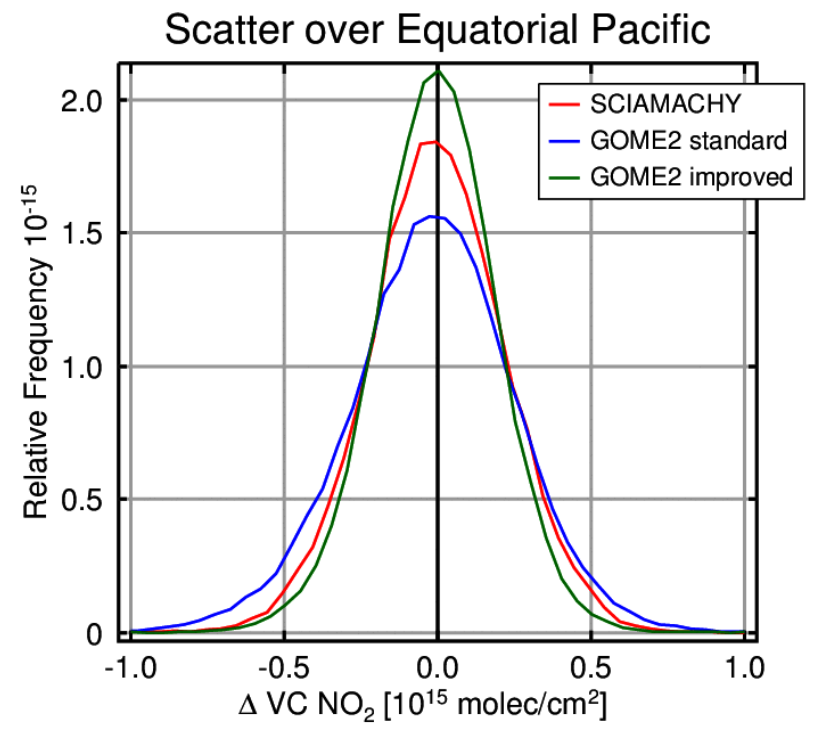

Fig. 2. Distribution of vertical $\mathrm{NO}_{2}$ columns over a clean region at the equatorial Pacific $\left(5^{\circ} \mathrm{S}-5^{\circ} \mathrm{N}, 150-210^{\circ} \mathrm{E}\right)$ for August 2007. A stratospheric airmass factor was applied, and only forward scans were included. All curves were normalised to have unit area and centred on 0. See text for details on the two different GOME-2 versions.

the integration time for individual measurements is comparable to that used for SCIAMACHY. In this context it is worthwhile to point out that GOME-2 throughput has reduced since launch as result of unexpected degradation, leading to an increase in fitting residuals by a factor of 1.5 until the end of 2009 (Dikty et al., 2010). The data shown here are not yet affected by this loss of signal.

In addition, a much larger scatter of $\mathrm{NO}_{2}$ values is observed in the region affected by the Southern Atlantic Anomaly (SAA), where an anomaly in the Earth's magnetic field leads to enhanced radiation exposure of the MetOp-A satellite. This is illustrated in Fig. 3 (left) for a single day of GOME-2 measurements, showing many outliers over South America and the Southern Atlantic. The effect of the SAA can also be seen in a strong increase in the residuals of the spectral retrievals (Fig. 4), which can be detected in a large area extending to South Africa. While problems in the region of the SAA are well known from other satellite missions, the impact on GOME-2 data appears to be larger than expected.

To improve the quality and applicability of the GOME-2 $\mathrm{NO}_{2}$ columns, the noise of the data should be reduced, in particular in the region of the SAA, while the consistency with the SCIAMACHY data is to be retained.

A reduction in noise can be achieved by averaging over data. Done in space, this will degrade the spatial resolution of the measurements which is to be avoided for tropospheric $\mathrm{NO}_{2}$ retrievals. Averaging can also be performed in time, e.g. by using monthly mean values. However, good temporal resolution is often desirable, limiting the applicability of averag- ing in time. Finally, the noise of the retrieval can also be reduced by including more spectral measurements and thereby additional information in the DOAS analysis through choice of a larger retrieval window which is the approach presented in the next section.

\section{Extension of the fitting window}

As mentioned above, the standard fitting window for $\mathrm{NO}_{2}$ used in the University of Bremen retrieval is $425-450 \mathrm{~nm}$. This window contains the largest differential structures of $\mathrm{NO}_{2}$ and has very little interference from other absorbers. It is therefore well suited for the $\mathrm{NO}_{2}$ retrieval. An overview on the relevant absorption cross-sections is given in Fig. 5. In principle, using more spectral points in the retrieval (extending the fitting window) should always improve the quality of the columns determined, as more measurement information contributes. However, this advantage of a larger fitting range can be cancelled by increased interference from other absorbers and, in the case of GOME and SCIAMACHY, by instrument polarisation features which strongly interfere with the retrieval of $\mathrm{NO}_{2}$. For GOME-2, no such instrumental problems exist close to the $\mathrm{NO}_{2}$ fitting range, and the analysis window can therefore be extended up to $497 \mathrm{~nm}$, short of a strong absorption by water vapour. Extension to shorter wavelengths is also possible but proved to have little impact on the retrievals and therefore is not further discussed here. The new settings used are listed in Table 1, the main difference to the original settings being the extended wavelength range and the inclusion of additional reference spectra which will be discussed later. In addition to these changes, the degree of the polynomial was also decreased in the new settings. This became possible as surface effects from liquid water and soil signals are now explicitly accounted for and do not have to be compensated by the polynomial.

The new retrieval settings have been applied to the full GOME-2 data set available (January 2007-October 2010), and good consistency was found with the standard retrieval, albeit with slightly larger $\mathrm{NO}_{2}$ columns in the new data set. As shown in Sect. 5, this improves the agreement with SCIAMACHY data. As expected, the new data set shows a clear reduction in scatter over clean regions, indicating a better signal to noise ratio. This is illustrated in Fig. 2, where SCIAMACHY and GOME-2 $\mathrm{NO}_{2}$ columns over the Pacific are compared also for the new retrieval. The spread of GOME-2 values now is smaller (FWHM $4.4 \times 10^{14} \mathrm{molec} \mathrm{cm}^{-2}$ ) than that of SCIAMACHY data $\left(5 \times 10^{14} \mathrm{molec} \mathrm{cm}^{-2}\right)$, which is a clear improvement relative to the standard retrieval.

When applying the larger fitting window to the GOME-2 data, it became apparent that the retrieval errors were systematically larger over regions with clear water and also over deserts. The effect of clean water oceanic regions on trace gas retrievals from satellite nadir measurements has been noted before (Richter et al., 2000; Vountas et al., 2003; Lerot 

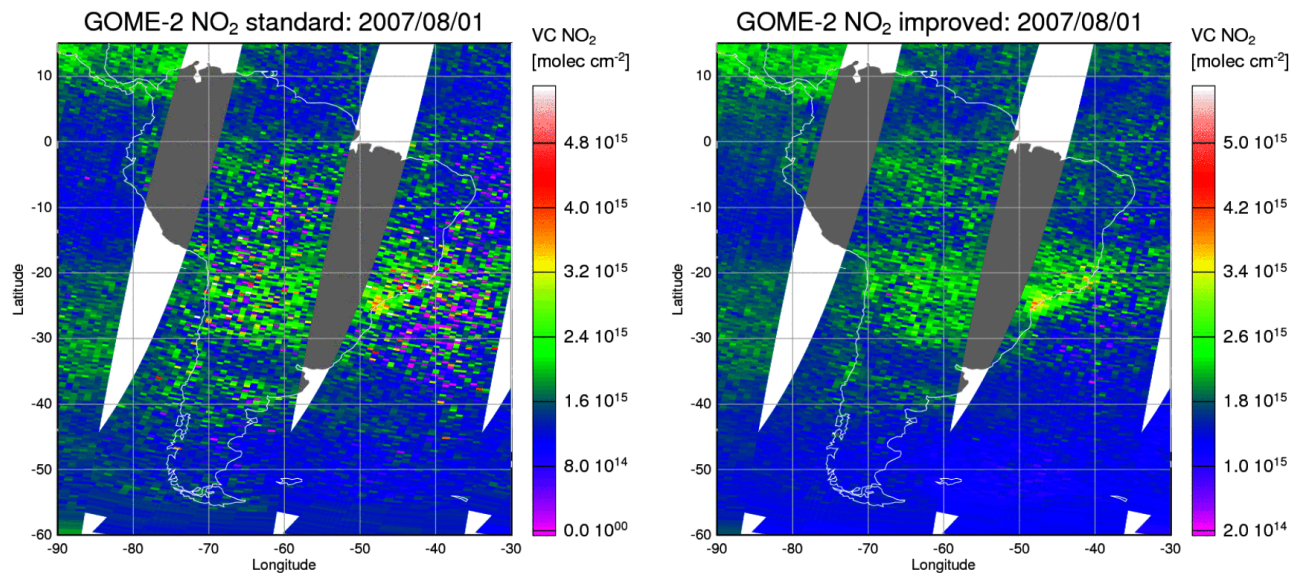

Fig. 3. Individual overpasses of GOME- $2 \mathrm{NO}_{2}$ data in the region of the Southern Atlantic Anomaly. Left: standard analysis, right: improved data product. Slightly different colour scales have been used to compensate for the small offset between the $\mathrm{NO}_{2}$ columns from the two retrievals.

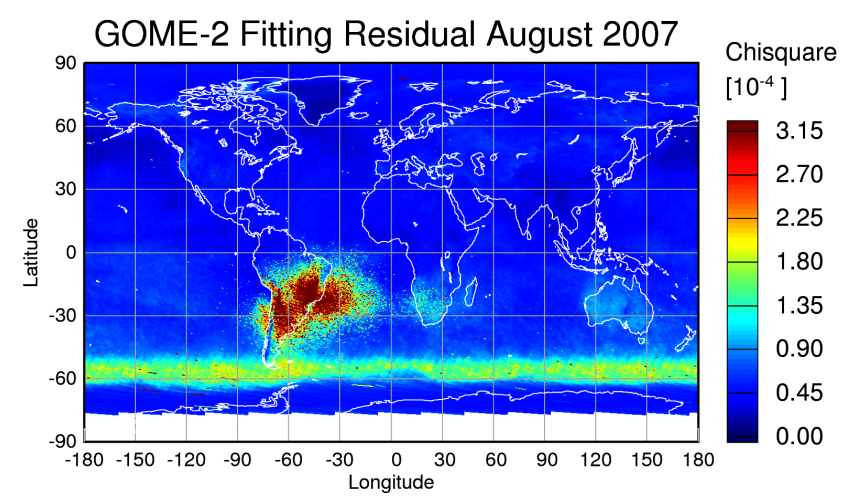

Fig. 4. Average fitting residual (chisquare) for all GOME-2 standard $\mathrm{NO}_{2}$ retrievals in August 2007. Larger values at high southern latitudes are the result of low intensities. At a certain solar zenith angle threshold, the integration time of GOME-2 measurements is increased, leading to smaller residuals at the highest southern latitudes.

et al., 2010). It has been explained by spectral interference between the absorption cross-sections of the trace gases and the spectra of both liquid water absorption and vibrational Raman scattering in the water column. Therefore, a liquid water absorption cross-section (Pope and Frey, 1997) is included in the new retrieval which accounts for most of the effect. An example of the spatial pattern retrieved for liquid water absorption is shown in Fig. 8, with high values over clean water bodies and low values elsewhere as expected. In contrast to the two phase approach suggested in Lerot et al. (2010), no special treatment of the liquid water absorption is needed here as the fitting window used is large enough to contain the main absorption structures. Vibrational Raman scattering is not considered explicitly, but partly compensated for with the inclusion of an additive offset in the fit

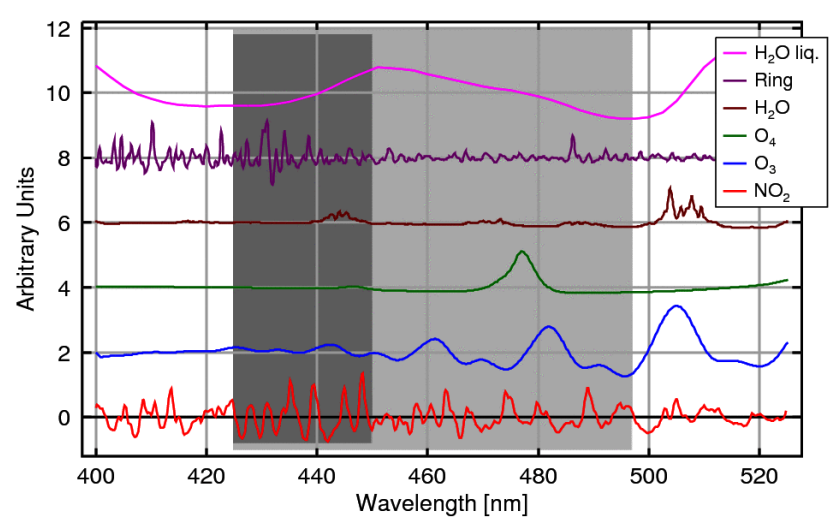

Fig. 5. Relevant differential absorption cross-sections in the spectral region used for the $\mathrm{NO}_{2}$ retrieval. High pass filtering was applied by subtraction of a polynomial of degree 3 from all cross-sections. The standard fitting window is shown in dark grey; the larger range of the improved retrieval is indicated in light grey. The individual lines are offset for clarity.

(Vountas et al., 2003). Inclusion of a calculated vibrational Raman correction spectrum would be preferable, but so far led to inconsistencies over land, which need to be solved before it can be relied on. Larger fit residuals were also observed over deserts, in particular over the Sahara. Surprisingly, the residuals improve when the liquid water reference is included in the analysis. However, the fit parameters for $\mathrm{H}_{2} \mathrm{O}_{\text {liq }}$ were not found to be 0 over the deserts as expected, but rather had significant negative values which is an unphysical result. It therefore was concluded that an additional spectral feature specific to sand or soil needs to be taken into account which has an accidental similarity to the liquid water absorption. An empirical approach was taken to deduce the spectral shape of the sand signal. Two individual cloud free near-nadir GOME-2 spectra were selected over North Africa, 


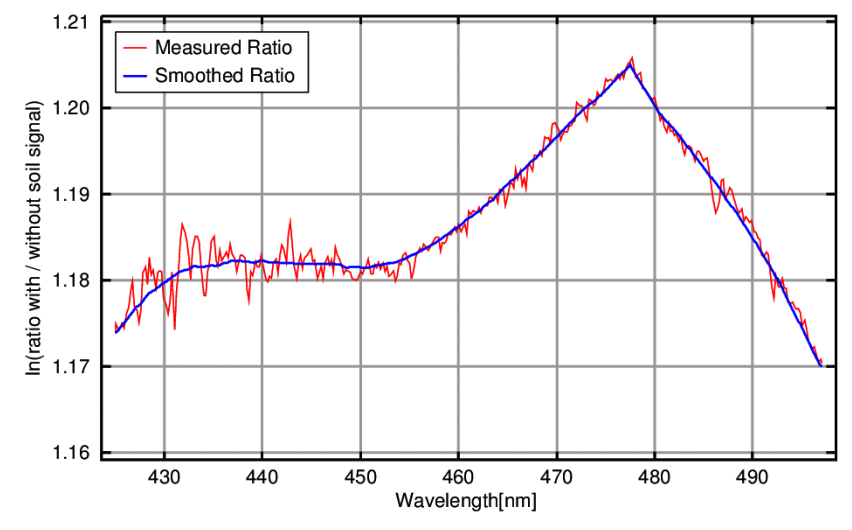

Fig. 6. Empirical soil signature derived from the logarithm of the ratio of two measurements from an orbit over the eastern Sahara. In the fit, the blue curve is used which has been smoothed to remove the residual signatures of the Ring effect clearly visible around $440 \mathrm{~nm}$. In order to maintain the sharp peak, smoothing has been performed over two separate regions left and right of $477.5 \mathrm{~nm}$. The two spectra used were taken on 1 August 2009 with centre co-ordinates at $\left(15.89^{\circ} \mathrm{N}, 25.43^{\circ} \mathrm{E}\right)$ and $\left(16.17^{\circ} \mathrm{N}, 23.99^{\circ} \mathrm{E}\right)$, respectively. The time difference between the two measurements was $0.375 \mathrm{~s}$ and the viewing line of sights at satellite were $2.76^{\circ}$ and $13.44^{\circ}$.

one having a small residual and the other one showing the high residuals found to be typical for deserts. Details on the location of the two measurements are given in the caption of Fig. 6. The natural logarithm of the ratio of these two spectra is shown in Fig. 6 before and after smoothing to remove structures from small differences in filling-in of Fraunhofer lines. It has an overall smooth shape with a pronounced edge close to $480 \mathrm{~nm}$. Very similar structures were found for many other ratios evaluated, indicating that this is a characteristic feature of measurements over sand. In order to verify the origin of this spectral structure, a very preliminary test was performed using the MAX-DOAS instrument on the roof of the IUP building in Bremen. On 9 February 2011, several measurements were made, alternating between pointing the instrument to a surface covered with sand from the Sahara and the zenith-sky. In Fig. 7, the logarithm of the ratio of two such measurements is compared to the soil signal derived from GOME-2. As the overall shape of the two signals is different, they were high-pass filtered using a polynomial of the same degree as applied in the DOAS fit. While there are differences between the two curves, the overall similarity lends confidence to their attribution to sand optical properties. Clearly, these measurements need to be repeated in a more systematic way using better light sources and observation geometries in a future study.

Inclusion of the empirical GOME-2 sand reference lead to a marked improvement of the fits over all desert regions, and also to better results than obtained using only the liquid water cross-section. In Fig. 8, the retrieved fit coefficients are shown for the sand signal in GOME-2 data from August

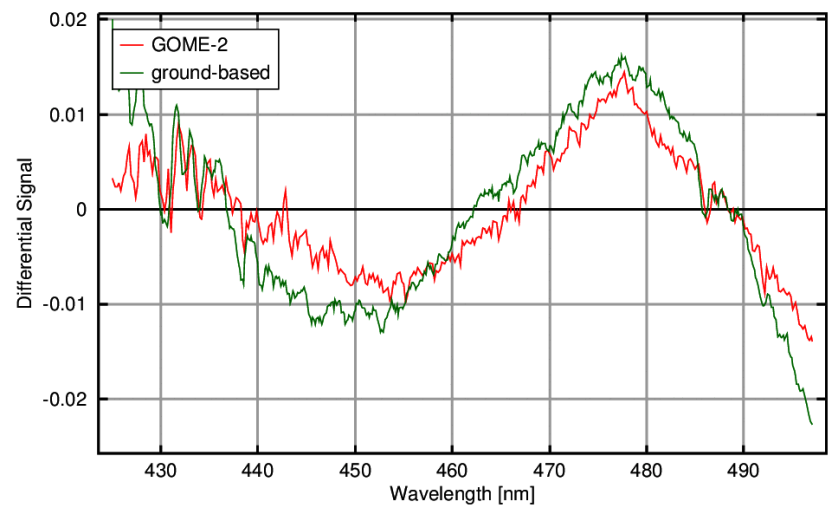

Fig. 7. Comparison of the GOME-2 soil signature with the logarithm of the ratio of two measurements performed with a groundbased spectrometer in Bremen, one pointing at a surface covered with sand from the Sahara and one pointing at the zenith-sky. As the overall shape of the two signals differs, a polynomial with 3 coefficients was subtracted, as it is done during the DOAS fit.

2007. As expected, the largest signals are found over deserts in Africa and Australia, but other regions with bare soil can also be detected, for example in the Canadian Arctic. Higher values are also observed over the ocean close to the estuary of the Amazon River and close to Africa during intense desert dust events (not shown). These results suggest that the signature is not unique to sand but is more generally linked to soil.

As the sand signature was determined empirically from the measurements, it cannot be fully ruled out that other atmospheric or instrumental effects are included. Desert scenes differ from other measurements for example by their higher surface reflectivity and resulting larger sensitivity to the lower troposphere, but also by the higher surface temperature. This could impact on the deduced cross-section, for example via a change in $\mathrm{O}_{4}$ column, Raman scattering, or the temperature dependence of the $\mathrm{O}_{4}$ absorption cross-section. In fact, the soil signature is quite similar to the $\mathrm{O}_{4}$ crosssection, and replacing the $\mathrm{O}_{4}$-cross-section used by that of Hermans et al. (1999) leads to a small change in the coefficients found for the soil signature, albeit without changing the spatial pattern. It can also be noted that over high altitude areas such as Greenland, the soil signal is systematically low which could indicate spectral correlation with the $\mathrm{O}_{4}$ crosssection. However, the detection of soil signatures in snow free but cold regions around Greenland and in the Arctic, as well as the absence of these signals in other bright regions (e.g. over snow and ice) and over the ocean, give confidence to the assignment of the observed signature to absorption effects by sand and some soils. For the future, it is highly desirable to replace this empirical cross-section by a high resolution laboratory measurement of the reflectance of sand or soil. Such measurements will also show whether or not the soil signature derived here is affected by other atmospheric or instrumental contributions. 


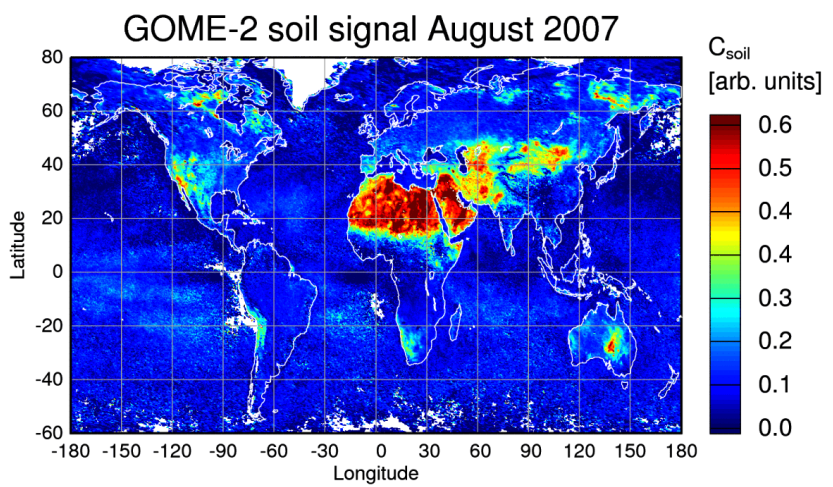

GOME-2 liquid water signal August 2007

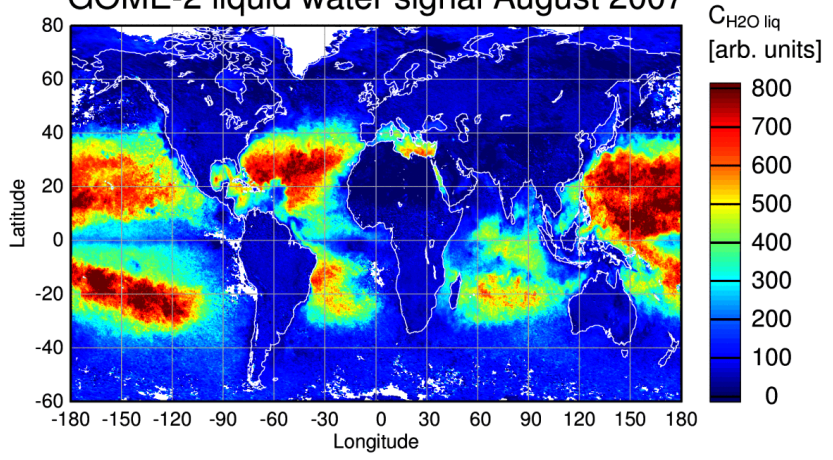

Fig. 8. Average fit coefficient of the empirical soil spectrum (top) and the liquid water spectrum (bottom) for August 2007. Only data with cloud fractions not larger than 0.2 have been included.

As discussed above, there appears to be a similarity between the liquid water absorption cross-section and the desert signature. This resemblance results in a clear anti-correlation of the values fitted for the two quantities in areas without a strong sand or water signal. In those cases, the fit cannot distinguish between the two quantities and the results for the individual components are small, noisy and meaningless. This is not the case over clear ocean waters and deserts where the attribution is unambiguous. An additional problem is a seasonally varying offset in the retrieved sand signals, which does not affect the observed pattern but the absolute value. This point will be further discussed in Sect. 5 .

While the detection of signals from liquid water and in particular from sand and soil is interesting and could be relevant for other retrievals and scientific applications, the effect on the retrieved $\mathrm{NO}_{2}$ columns proved to be small. The same is true for the inclusion of the so called Eta calibration function which is a representation of the polarisation sensitivity of the GOME-2 instrument measured before launch. Adding Eta as a pseudo-absorber in the retrieval improves the fit residuals for the eastern part of the swath, indicating some remaining calibration issues with GOME-2 radiances. However, this addition only marginally affects the retrieved $\mathrm{NO}_{2}$ columns.

Increasing the size of the fitting window as has also been done for the OMI $\mathrm{NO}_{2}$ retrievals which use wavelengths

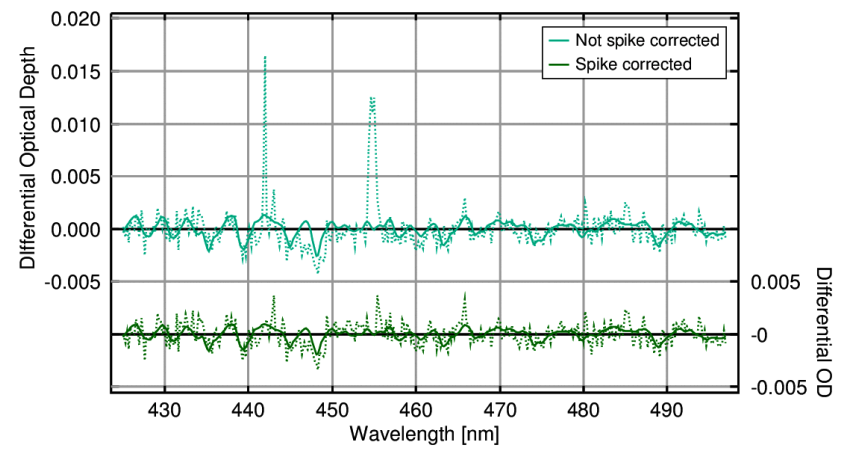

Fig. 9. Example for a fit in the Southern Atlantic Anomaly region affected by spikes. Shown are the scaled differential crosssection (solid lines) and the sum of scaled cross-section and residual (dotted lines). The original retrieval is shown in the upper part and the retrieval after spike removal in the lower part of the figure. The retrieved $\mathrm{NO}_{2}$ slant columns are $9.3 \times 10^{15}$ and $6.9 \times 10^{15}$ molec $\mathrm{cm}^{-2}$ without and with spike correction, respectively.

from $405-465 \mathrm{~nm}$ (Buscela et al., 2006). Any change in wavelength window used has important implications on the interpretation of the slant columns. Most importantly, the airmass factor will vary over the fitting window as result of the wavelength dependence of Rayleigh scattering, in particular in the presence of large tropospheric $\mathrm{NO}_{2}$ amounts. This change will be even larger over surfaces such as bare soil or vegetation, which have a spectral surface reflectance that can vary by several per cent over the spectral interval used (Kleipool et al., 2008). For the same reasons, the effective cloud fraction is a function of wavelength. Depending on instrument design, even the ground scene observed varies slightly with wavelength, potentially creating further differences between retrievals performed at different fitting windows. All these effects need to be considered when using the results from a larger fitting window in atmospheric applications.

\section{Removal of spikes in the Southern Atlantic Anomaly}

In the region of the Southern Atlantic Anomaly, the satellite instrument is subject to an increased particle flux which creates spurious signals in individual detector pixels and can also affect the readout and amplification electronics. As a result, the residuals of the fit are much larger than in other regions, affecting the quality of the retrieved slant columns. The traditional way of accounting for this problem is to remove measurements with poor fits from the results, but this leads to a loss of the majority of all data over parts of South America and therefore is not a satisfactory solution.

However, often only a few individual detector pixels are affected as illustrated in Fig. 9. In these cases, it should be possible to identify and remove the noisy 
points from the fit. An algorithm based on the fact that such spikes affect only short time periods and small parts of the detector has been developed for the OMI instrument and is applied in the calibration of the data (see the Supplement at http://www.atmos-meas-tech-discuss.net/ 4/C143/2011/amtd-4-C143-2011-supplement.pdf for a document describing the algorithm). As the amplitude of the distortion is usually only of the order of a few percent or less, it cannot always be found in the highly structured spectra themselves. This is particularly the case for GOME-2, which uses diode array detectors having a large full-well capacity and consequently a smaller effect of an individual particle event. Higher sensitivity for spikes can however be achieved by analysing the residual of the fit where the contribution of the Fraunhofer lines, scattering, and absorption is already removed.

Therefore, the approach described here is to perform a first DOAS fit, and then iteratively scan the residual for points having a value larger than 10 times the average residual of the fit. The current point as well as values already identified as outliers are not included in the average. This procedure is repeated until no further outliers are identified. If outliers are found, they are assigned a very large error $\left(1.0 \times 10^{34}\right)$ and the DOAS retrieval is repeated. By applying this procedure to all fits, the scatter in the SAA region is largely reduced, and, in addition, spurious bad pixels are removed in other regions. This is illustrated in Fig. 10, where results from one orbit crossing the SAA are shown for the two retrievals. Most of the outliers are corrected and the reduced scatter in other regions is also apparent.

The effect of peak removal on the data quality is further illustrated in Fig. 3, where the same data are shown for the standard and improved analysis. Clearly, the noise is much reduced, facilitating geophysical interpretation of all data including the problematic SAA region. Some bad pixels remain, and screening for too large residuals still has to be applied before applying the data. It should be noted that part of the improvement seen in Figs. 3 and 10 is due to the larger fitting window used, which reduces the scatter and is inherently less affected by individual spikes. Also, removal of several spectral points is less problematic in the case of a larger fitting window than for a small range using only few measurements. Therefore, application of spike removal to the original smaller wavelength window proved much less successful than for the large window.

The choice of the cut-off parameter for the removal of bad pixels introduces some arbitrariness in the retrieval. Lowering the threshold further reduces the scatter over the SAA but increases the noise at lower sun where the intensity is smaller and the retrieval inherently more noisy. Moreover, systematic changes in $\mathrm{NO}_{2}$ columns are observed for low sun when using too small thresholds which illustrates a general problem: removing measurement pixels with larger residuals assumes that the fit is perfect and the only reason for outliers is measurement noise which is not necessarily the case.

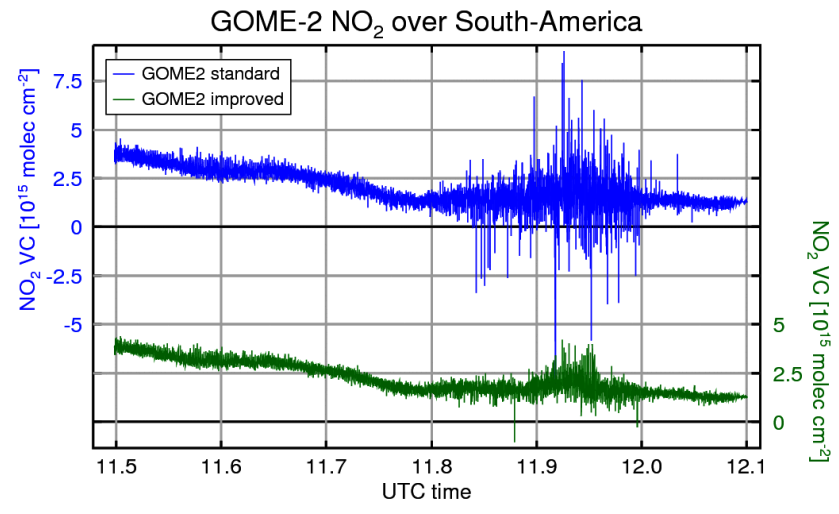

Fig. 10. Example of the difference in effect of the Southern Atlantic Anomaly on an individual orbit. Results from the standard evaluation are shown in the upper part of the figure, the improved results in the lower part. The orbit shown is the right orbit in Fig. 3 passing over the eastern part of South America on 1 August 2007.

Therefore, application of the spike removal approach always needs to be carefully monitored to avoid biasing the data. This is best done by comparing $\mathrm{NO}_{2}$ columns with and without spike correction in regions outside the SAA where spike correction should leave the values unchanged.

\section{Comparison to SCIAMACHY data}

To evaluate the overall quality of the improved GOME-2 $\mathrm{NO}_{2}$ columns, they can be compared to SCIAMACHY data from the same day. As the measurement and retrieval of the two data sets is very similar, this should not be viewed as validation but rather as verification of the GOME-2 data set. However, the comparison provides excellent statistics at all latitudes and over the full time period of GOME-2 measurements.

In Fig. 11, time series of GOME-2 and SCIAMACHY $\mathrm{NO}_{2}$ are compared for 2007-2009 over selected $10^{\circ}$ latitude bins taken over the clean Pacific region $\left(180^{\circ} \mathrm{E}-220^{\circ} \mathrm{E}\right)$. A stratospheric airmass factor was applied, as the impact of tropospheric pollution is expected to be small in this area. In this case, possible changes in surface spectral reflectance between the two fitting windows do not have a significant impact on the results. As can be seen, the overall agreement of the two data sets is excellent with the GOME-2 data reproducing the day-to-day, seasonal, latitudinal and inter-annual variation seen in the SCIAMACHY time series. There is no indication of a systematic bias between the two data sets, nor for a temporal drift of the differences.

The agreement is however not perfect and closer inspection of the differences between the GOME-2 and SCIAMACHY data sets (also shown in Fig. 11) reveals systematic patterns of deviations with maximum values of $2-$ $4 \times 10^{14} \mathrm{molec} \mathrm{cm}^{-2}$ in January/February and July/August. 


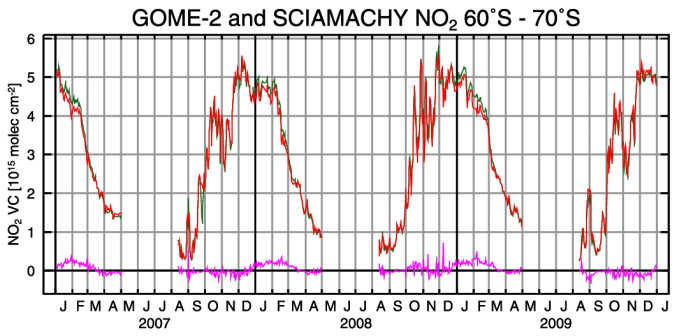

GOME-2 and SCIAMACHY $\mathrm{NO}_{2} 40^{\circ} \mathrm{S}-50^{\circ} \mathrm{S}$

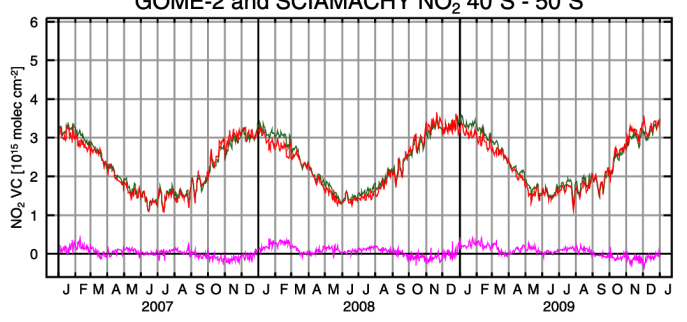

GOME-2 and SCIAMACHY NO $20^{\circ} \mathrm{S}-20^{\circ} \mathrm{S}$

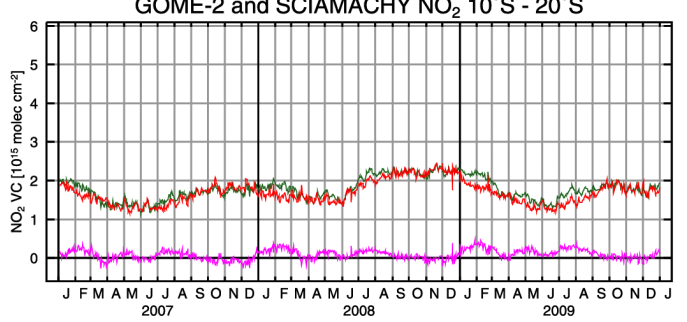

GOME-2 and SCIAMACHY $\mathrm{NO}_{2} 60^{\circ} \mathrm{N}-70^{\circ} \mathrm{N}$

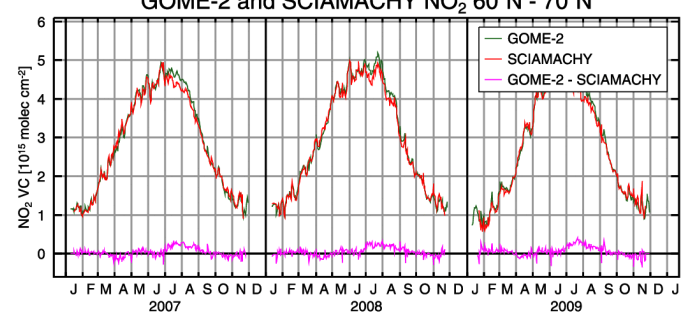

GOME-2 and SCIAMACHY $\mathrm{NO}_{2} 40^{\circ} \mathrm{N}-50^{\circ} \mathrm{N}$

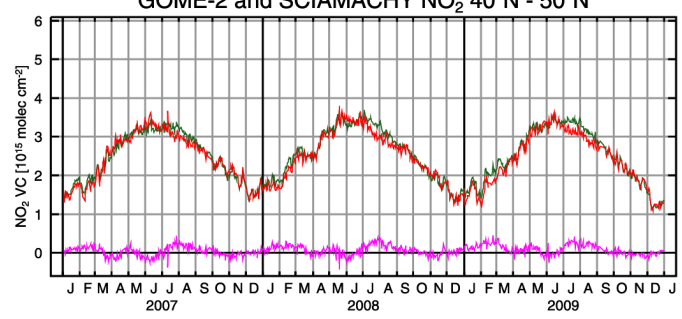

GOME-2 and SCIAMACHY $\mathrm{NO}_{2} 10^{\circ} \mathrm{N}-20^{\circ} \mathrm{N}$

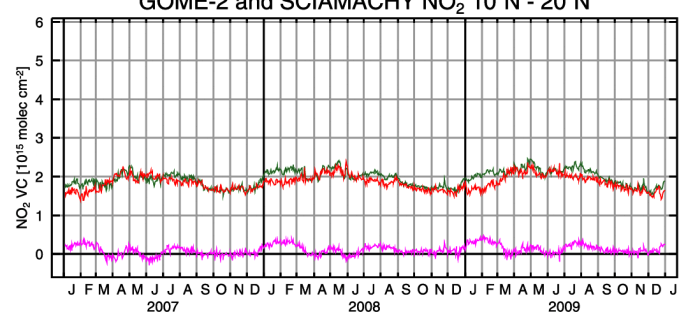

Fig. 11. Comparison of three years of daily GOME-2 (green) and SCIAMACHY (red) $\mathrm{NO}_{2}$ over the Pacific $\left(180^{\circ} \mathrm{E}-220^{\circ} \mathrm{E}\right)$ for selected $10^{\circ}$ latitude bands in the southern (left) and northern hemisphere (right). A stratospheric airmass factor was applied to both data sets. Also shown is the difference GOME-2 - SCIAMACHY (pink).

The temporal evolution of the differences is very similar in all three years, but also at all latitudes and in both hemispheres. The amplitude of the differences is largest at low latitudes and smallest at high latitudes in winter. This pattern is indicative of an offset on the slant columns of either GOME2 or SCIAMACHY (or both), which has a systematic seasonal variation. Such an effect has been observed in GOME data and was explained by an interference pattern produced by the diffuser plate used in the solar irradiance measurements (Richter and Wagner, 2001; Martin et al., 2002). As the incident angle of the solar radiation on the diffuser varies over the course of a year, the interference pattern and thus the impact on the $\mathrm{NO}_{2}$ columns shows a temporal variation which is repeated each year. The effect is to add an offset to all slant columns which is globally constant but varies from day to day. This results in large errors at low latitudes and during summer but is less important at high latitudes in winter when the airmass factor is large. The diffuser plates used in the SCIAMACHY and GOME-2 instruments have been improved in comparison to the one used in GOME, although some residual effect of the solar measurements cannot be excluded, probably as result of interference within the diffusor or from other optical components in the solar irradiance measurement light path. In fact, a recent study reported a clear impact of the solar spectrum selected on glyoxal $\left(\mathrm{C}_{2} \mathrm{H}_{2} \mathrm{O}_{2}\right)$ retrievals from GOME-2 measurements (Lerot et al., 2010).

In order to investigate the relevance of the solar spectrum used, data for the year 2008 were also analysed using a single solar spectrum, arbitrarily selected to be from 1 July 2008. The correlation between GOME-2 and SCIAMACHY measurements over the area with the smallest seasonal variability $\left(180^{\circ} \mathrm{E}-220^{\circ} \mathrm{E}, 10^{\circ} \mathrm{S}-0^{\circ} \mathrm{S}\right)$ improves from 0.62 to 0.84 if this fixed solar spectrum is used for the GOME-2 analysis. When the SCIAMACHY data is also analysed using a single solar spectrum from 1 July, the correlation further increases to 0.91 . This clearly indicates an impact of the solar measurements on the retrieved $\mathrm{NO}_{2}$ column, both in GOME2 and in SCIAMACHY data, similar to what was reported for GOME. However, the size of the effect (smaller than $2 \times 10^{14}$ molec cm$^{-2}$ ) is much smaller than that reported for the GOME instrument (up to $1.5 \times 10^{15} \mathrm{molec} \mathrm{cm}^{-2}$, (Richter and Wagner, 2001). When using the fixed solar spectra, the two data sets differ by a nearly constant offset of $2 \times 10^{14} \mathrm{molec} \mathrm{cm}^{-2}$ (see Fig. 12). The origin of this offset is unclear, but it could be related to the choice of solar background spectrum which can introduce changes of this order of magnitude. However, other differences (time of overpass, cross-sections, instrumental problems) could also contribute to the differences. 


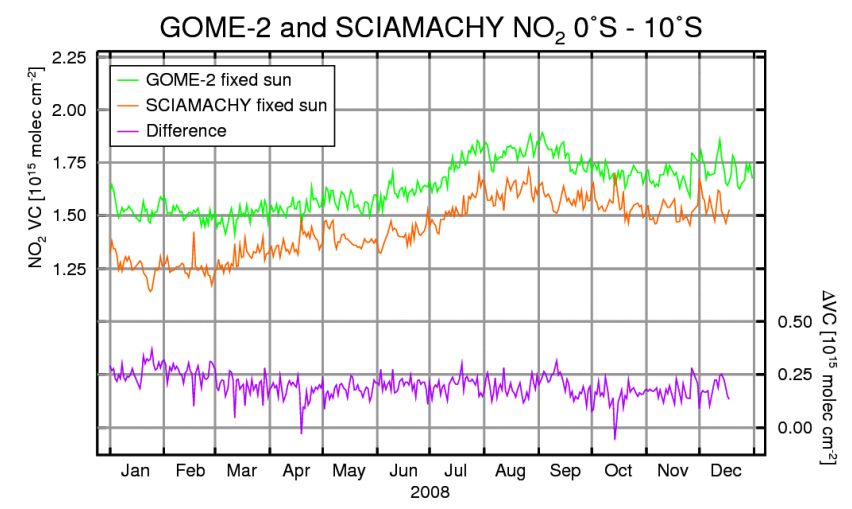

Fig. 12. Comparison of daily GOME-2 (green) and SCIAMACHY (red) $\mathrm{NO}_{2}$ over the Pacific $\left(180^{\circ} \mathrm{E}-220^{\circ} \mathrm{E}, 10^{\circ} \mathrm{S}-0^{\circ} \mathrm{S}\right)$ using the same retrievals as in Fig. 11, but with solar irradiance measurements form 1 July 2008 as background spectrum. The difference of the two time series is also shown (pink).

Using fixed solar spectra also significantly improves the agreement between the new and the original GOME-2 time series at low latitudes, as the effect of the solar spectrum is even larger for the small fitting window (not shown). The consistency between GOME-2 and SCIAMACHY is also improved at higher latitudes, in particular in the southern hemisphere in January/February, but some systematic differences of the order of $1 \times 10^{14}$ molec $\mathrm{cm}^{-2}$ remain unexplained. As for $\mathrm{NO}_{2}$, the fit coefficients for other cross-sections in the retrieval also show unexpected systematic seasonal patterns which are reduced when using a fixed solar background spectrum. This is in particular the case for the liquid water and soil signals which can be negative for large areas in some months when using daily solar spectra.

From this analysis, the use of a single solar spectrum appears to be the optimum choice for the GOME-2 (and SCIAMACHY) $\mathrm{NO}_{2}$ retrievals. However, the use of daily solar spectra offers the advantage of more complete cancellation of the effects of instrument degradation, and in fact, the fit quality systematically deteriorates with the time difference between measurement and solar background used (not shown). While this may be acceptable for a time series of a few months, it cannot be extended to the complete data set, particularly after the 2nd throughput test of GOME-2 (September 2009) and the associated changes in instrument response (Dikty et al., 2010). Use of a solar spectrum averaged for a time period around the measurement could reduce the effect but cannot solve it completely. It should also be noted that most retrieval approaches for tropospheric $\mathrm{NO}_{2}$ apply a correction of the stratospheric component by subtracting values observed over clean areas on the same day. By this procedure, offsets as those introduced by the daily solar measurements cancel and do not affect the final results. In summary, we conclude that the use of the daily solar spectrum still is the best choice for a consistent long-term dataset and there-

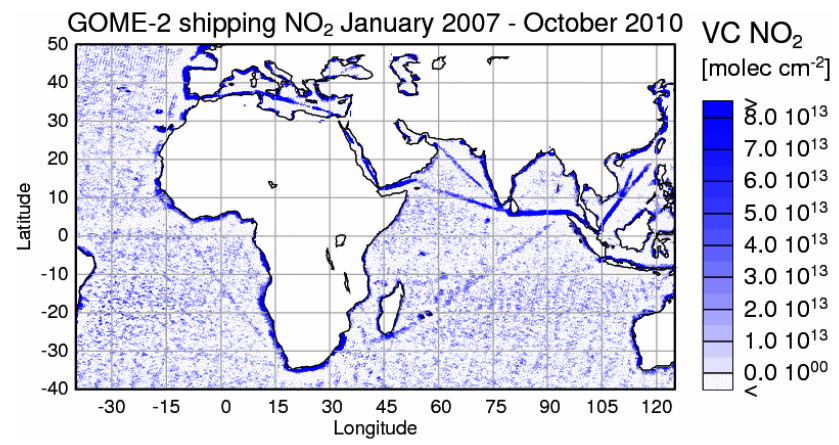

Fig. 13. Long-term average of tropospheric $\mathrm{NO}_{2}$ columns derived from the improved GOME- $2 \mathrm{NO}_{2}$ data set. Data have been spatially high pass filtered to highlight the signals from ship emission. See text for details.

fore this is the choice made in the current GOME-2 data set. Future improvements in instrument calibration will hopefully solve the problem related to the solar measurements and further reduce the uncertainty of the $\mathrm{NO}_{2}$ columns.

\section{Application to the $\mathrm{NO}_{2}$ signature of ships}

International shipping is a significant and growing source of pollution in the marine boundary layer (Eyring et al., 2007). Large amounts of relatively dirty fuels are burned by ships transporting raw materials and goods around the globe, and often these emissions are concentrated along well defined shipping lanes, frequented by many vessels. Although the $\mathrm{NO}_{2}$ signal from shipping is relatively small, ship emissions between Africa, India, and Indonesia have been identified in long-term averages of GOME data (Beirle et al., 2004). Using data from the SCIAMACHY instrument, which has better spatial resolution, these and additional ship tracks through the Red Sea and towards China and Japan could be identified much more clearly already in less than $2 \mathrm{yr}$ worth of data (Richter et al., 2004). In a study applying OMI data, $\mathrm{NO}_{2}$ from ships was also observed in the Mediterranean (Marmer et al., 2009). More recently, Franke et al. (2009) compared modelled and satellite observed $\mathrm{NO}_{2}$ for the shipping lane between India and Indonesia using GOME, SCIAMACHY, OMI, and GOME-2 (standard fit) data, finding indication of an upward trend in shipping emissions.

Here, we evaluate the new GOME- $2 \mathrm{NO}_{2}$ dataset for the signature of $\mathrm{NO}_{2}$ from ships. Nearly $4 \mathrm{yr}$ of data (January 2007-October 2010) were used in a three step procedure to identify shipping $\mathrm{NO}_{2}$ : First, monthly averages of GOME-2 tropospheric $\mathrm{NO}_{2}$ were computed using the simple reference sector method and applying an airmass factor appropriate for an albedo of $5 \%$ and a $700 \mathrm{~m}$ thick layer of $\mathrm{NO}_{2}$ in the marine boundary layer. These settings are identical to those used in previous studies (Richter et al., 2004; Franke et al., 2009). The data were then averaged over all months of the period 
resulting in a long-term mean tropospheric field. Some shipping $\mathrm{NO}_{2}$ is readily visible in this average, but a clearer picture is obtained by applying a spatial high pass filter. For this, continents were masked out and the smoothed field (boxcar, $3.75^{\circ} \times 3.75^{\circ}$ ) was subtracted from the average. The resulting $\mathrm{NO}_{2}$ map is shown in Fig. 13. In addition to the shipping lanes already identified in earlier work, a line of $\mathrm{NO}_{2}$ can be seen around Europe towards the Mediterranean and all the way to the Red Sea, but also from Europe around Africa towards Indonesia and in the Black Sea towards the Bosporus. There also are hints of shipping lanes from South and North Africa towards South America, but these signals are nearly lost in the noise.

The data in Fig. 13 have not been screened or corrected for the impact of clouds. Tests with different cloud screening thresholds between $5 \%$ and $100 \%$ have shown a surprisingly small impact of this choice on the results in the shipping lane with the strongest signal (this was already reported in Franke et al. (2009) for the standard retrieval). However, the weaker shipping lanes can hardly be seen in cloud screened data, probably because the gain in signal from clear scenes is more than out-weighted by the increase in noise from the smaller number of measurements used in the average. The missing cloud treatment and the uncertainty introduced by the assumptions made on the airmass factor make these results rather qualitative; however, they demonstrate that in a $4 \mathrm{yr}$ average, the noise level in the new GOME-2 $\mathrm{NO}_{2}$ data is low enough to identify signals as small as several $10^{13}$ molec cm $^{-2}$.

\section{Summary and conclusions}

An improved GOME-2 $\mathrm{NO}_{2}$ slant column dataset has been created using an extended fitting window (425-497 nm) and an explicit spike removal algorithm to reduce the noise in the data. Compared to the standard retrieval, the scatter of the stratospheric vertical columns has been reduced from $5.8 \times 10^{14}$ to $4.4 \times 10^{14}$ molec cm$^{-2}$ over the equatorial Pacific, now being lower than in results using data from the SCIAMACHY instrument. The negative impact of the Southern Atlantic Anomaly on the retrieved columns is greatly reduced in the improved data set, facilitating geophysical interpretation of the data over South America.

Comparison of GOME-2 and SCIAMACHY $\mathrm{NO}_{2}$ columns shows very good agreement at all latitudes and seasons. There is however a small, seasonally varying difference of up to $2-4 \times 10^{14}$ molec $\mathrm{cm}^{-2}$ depending on latitude which could be explained by a systematic offset introduced by changes in the solar spectra used in both data sets. This offset can be removed for shorter time periods by using a single instead of daily solar background measurements, but this comes at the price of increased fitting residuals and inconsistencies after instrumental changes and therefore is not applicable for analysis of the full data set. The remaining un- explained differences between GOME-2 and SCIAMACHY are smaller than $2 \times 10^{14}$ molec $\mathrm{cm}^{-2}$ for daily values which is considered to be excellent agreement.

In the extended fitting range used for the new GOME-2 $\mathrm{NO}_{2}$ product, an unexpected but clear spectral signature of sand and soil could be identified. Inclusion of this empirical signal in the retrieval reduces fitting residuals and yields global maps of surfaces covered by sand or bare soil. The sand signature is also found close to the estuary of the Amazon River and in cases of very high desert aerosol loading also over water scenes. Here, the soil signature is used as a correction factor, but it could provide interesting information on surface properties and desert dust aerosols in the future.

As an example application, an average over nearly $4 \mathrm{yr}$ of the new $\mathrm{NO}_{2}$ data was analysed for shipping $\mathrm{NO}_{2}$ signatures. Several shipping lanes could be detected which have not been observed before from space (around Africa and also in the Black Sea), illustrating the excellent signal to noise ratio of the data.

In summary, the new GOME-2 $\mathrm{NO}_{2}$ retrieval has significantly less noise than the standard product, and at the same time has good consistency to the existing SCIAMACHY data record. It is therefore well suited to extend the $\mathrm{NO}_{2}$ data set into the future and to investigate effects with relatively small $\mathrm{NO}_{2}$ signatures. The approaches taken here, namely the use of a larger fitting window and the two-step removal of spikes in the spectra could potentially also be applied to other retrievals, and spike correction has already successfully been incorporated into the IUP Bremen GOME-2 $\mathrm{SO}_{2}$ data.

Acknowledgements. GOME-2 lv1 data have been provided by EUMETSAT. SCIAMACHY lv1 data have been provided by ESA through DLR. Parts of this work were funded by the State of Bremen, the University of Bremen and the European Union through the CITYZEN project. A. Hilboll gratefully acknowledges funding by the Earth System Science Research School (ESSReS), an initiative of the Helmholtz Association of German research centres (HGF) at the Alfred Wegener Institute for Polar and Marine Research. The authors would like to thank two anonymous reviewers for their useful comments and suggestions.

Edited by: F. Boersma

\section{References}

Beirle, S., Platt, U., Wenig, M., and Wagner, T.: Weekly cycle of $\mathrm{NO}_{2}$ by GOME measurements: a signature of anthropogenic sources, Atmos. Chem. Phys., 3, 2225-2232, doi:10.5194/acp-32225-2003, 2003.

Beirle, S., Platt, U., von Glasow, R., Wenig, M., and Wagner, T.: Estimate of nitrogen oxide emissions from shipping by satellite remote sensing, Geophys. Res. Lett., 31, L18102, doi:10.1029/2004GL020312, 2004.

Boersma, K. F., Eskes, H. J., and Brinksma E. J.: Error Analysis for Tropospheric $\mathrm{NO}_{2}$ Retrieval from Space, J. Geophys. Res., 109, D04311, doi:10.1029/2003JD003962, 2004. 
Boersma, K. F., Jacob, D. J., Eskes, H. J., Pinder, R. W., Wang, J., and van der A, R. J.: Intercomparison of SCIAMACHY and OMI tropospheric $\mathrm{NO}_{2}$ columns: Observing the diurnal evolution of chemistry and emissions from space, J. Geophys. Res., 113, D16S26, doi:10.1029/2007jd008816, 2008.

Bovensmann, H., Burrows, J. P., Buchwitz, M., Frerick, J., Noël, S., Rozanov, V. V., Chance, K. V., and Goede, A. H. P.: SCIAMACHY - Mission objectives and measurement modes, J. Atmos. Sci., 56(2), 127-150, 1999.

Brewer A. C., McElroy, C. T., and Kerr, J. B.: Nitrogen dioxide concentrations in the atmosphere, Nature, 246, 129-133, 1973.

Bucsela, E. J., Celarier, E. A., Wenig, M. O., Gleason, J. F., Veefkind, J. P., Boersma, K. F., and Brinksma, E. J.: Algorithm for $\mathrm{NO}_{2}$ vertical column retrieval from the ozone monitoring instrument, IEEE Transactions on Geoscience and Remote Sensing, 5, 1245-1258, 2006.

Burrows, J. P., Weber, M., Buchwitz, M., Rozanov, V., LadstätterWeißenmayer, A., Richter, A., DeBeek, R., Hoogen, R., Bramstedt, K., Eichmann, K.-U., Eisinger, M., and Perner, D: The Global Ozone Monitoring Experiment (GOME): Mission Concept and First Scientific Results, J. Atmos. Sci., 56, 151-175, 1999.

Callies, J., Corpaccioli, E., Eisinger, M., Hahne, A., and Lefebvre, A.: GOME-2- Metop's second-generation sensor for operational ozone monitoring, ESA Bull., 102, 28-36, 2000.

Chu, W. P. and McCormick M. P.: SAGE Observations of Stratospheric Nitrogen Dioxide, J. Geophys. Res., 91(D5), 5465-5476, doi:10.1029/JD091iD05p05465, 1986.

Dikty, S., Richter, A., Bovensmann, H., Wittrock, F., Weber, M., Noël, S., Burrows, J. P., Munro, R., and Lang, R.: GOME-2 level 2 products at IUP Bremen and first results on the quantification of the effects of optical degradation, poster at the 2010 EUMETSAT Meteorological Satellite Conference, Córdoba, Spain, available at: http://www.doas-bremen.de/posters/eumetsat_2010_dikty.pdf 20-24 September 2010.

Eyring, V., Stevenson, D. S., Lauer, A., Dentener, F. J., Butler, T., Collins, W. J., Ellingsen, K., Gauss, M., Hauglustaine, D. A., Isaksen, I. S. A., Lawrence, M. G., Richter, A., Rodriguez, J. M., Sanderson, M., Strahan, S. E., Sudo, K., Szopa, S., van Noije, T. P. C., and Wild, O.: Multi-model simulations of the impact of international shipping on Atmospheric Chemistry and Climate in 2000 and 2030, Atmos. Chem. Phys., 7, 757-780, doi:10.5194/acp-7-757-2007, 2007.

Franke, K., Richter, A., Bovensmann, H., Eyring, V., Jöckel, P., Hoor, P., and Burrows, J. P.: Ship emitted $\mathrm{NO}_{2}$ in the Indian Ocean: comparison of model results with satellite data, Atmos. Chem. Phys., 9, 7289-7301, doi:10.5194/acp-9-7289-2009, 2009.

Greenblatt, G. D., Orlando, J. J., Burkholder, J. B., and Ravishankara, A. R.: Absorption measurements of oxygen between 330 and 1140 nm, J. Geophys. Res., 95, 18577-18582, 1990.

Hermans, C., Vandaele, A. C., Carleer, M., Fally, S., Colin, R., Jenouvrier, A., Coquart, B., and Merienne, M. F.: Absorption cross-sections of atmospheric constituents: $\mathrm{NO}_{2}, \mathrm{O}_{2}$, and $\mathrm{H}_{2} \mathrm{O}$, Environ. Sci. Pollut. R., 6, 151-158, 1999.

Ionov, D. V., Timofeyev, Y. M., Sinyakov, V. P., Semenov, V. K., Goutail, F., Pommereau, J.-P., Bucsela, E. J., Celarier, E. A., and Kroon, M.: Ground-based validation of EOS-Aura OMI $\mathrm{NO}_{2}$ vertical column data in the midlatitude mountain ranges of Tien
Shan (Kyrgyzstan) and Alps (France), J. Geophys. Res., 113, D15S08, doi:10.1029/2007JD008659, 2008.

Kleipool, Q. L., Dobber, M. R., de Haan, J. F., and Levelt, P. F.: Earth surface reflectance climatology from 3 years of OMI data, J. Geophys. Res., 113, D18308, doi:10.1029/2008JD010290, 2008.

Lerot, C., Stavrakou, T., De Smedt, I., Müller, J.-F., and Van Roozendael, M.: Glyoxal vertical columns from GOME-2 backscattered light measurements and comparisons with a global model, Atmos. Chem. Phys., 10, 12059-12072, doi:10.5194/acp10-12059-2010, 2010.

Leue, C., Wenig, M., Wagner, T., Platt, U., and Jähne, B.: Quantitative analysis of NOx emissions from GOME satellite image sequences, J. Geophys. Res., 106, 5493-5505, 2001.

Levelt, P. F., van den Oord, G. H. J., Dobber, M. R., Mälkki, A., Visser, H., de Vries, J., Stammes, P., Lundell J., and Saari, H.: The Ozone Monitoring Instrument, IEEE Trans. Geo. Rem. Sens., 44(5), 1093-1101, doi:10.1109/TGRS.2006.872333, 2006.

Liley, J. B., Johnston, P. V., McKenzie, R. L., Thomas, A. J., and Boyd I. S.: Stratospheric $\mathrm{NO}_{2}$ variations from a long time series at Lauder, New Zealand, J. Geophys. Res., 105(D9), 11633 11640, doi:10.1029/1999JD901157, 2000.

Marmer, E., Dentener, F., Aardenne, J. v., Cavalli, F., Vignati, E., Velchev, K., Hjorth, J., Boersma, F., Vinken, G., Mihalopoulos, N., and Raes, F.: What can we learn about ship emission inventories from measurements of air pollutants over the Mediterranean Sea?, Atmos. Chem. Phys., 9, 6815-6831, doi:10.5194/acp-96815-2009, 2009.

Martin, R. V., Chance, K. , Jacob, D. J., Kurosu, T. P., Spurr, R. J. D., Bucsela, E., Gleason, J. F., Palmer, P. I., Bey, I., Fiore, A. M. , Li, Q., Yantosca R. M., and Koelemeijer R. B.: An improved retrieval of tropospheric nitrogen dioxide from GOME, J. Geophys. Res, 107, 4437-4456, 2002.

Mijling, B., van der A, R. J., Boersma, K. F., Van Roozendael, M., De Smedt, I., and Kelder, H. M.: Reductions of $\mathrm{NO}_{2}$ detected from space during the 2008 Beijing Olympic Games, Geophys. Res. Lett., 36, L13801, doi:10.1029/2009GL038943, 2009.

Noxon, J. F.: Nitrogen dioxide in the stratosphere and troposphere measured by ground-based absorption spectroscopy, Science, 189, 547-549, 1975.

Platt, U.: Differential optical absorption spectroscopy (DOAS), in: Air Monitoring by Spectroscopic Techniques, edited by: Sigrist, M. W., Chemical Analysis Series, John Wiley, New York, 127, 27-84, 1994.

Pope, R. M. and Fry, E. S.: Absorption spectrum (380-700 nm) of pure water. II. Integrating cavity measurements, Appl. Opt., 36, 8710-8723, 1997.

Richter, A. and Burrows, J. P.: A multi-wavelength approach to the retrieval of tropospheric $\mathrm{NO}_{2}$ from GOME measurements, in proceedings of the ERS-ENVISAT symposium, Gothenburg October 2000, ESA publication SP-461, available at: http://earth. esa.int/pub/ESA_DOC/gothenburg/244richt.pdf, 2000.

Richter, A. and Burrows, J. P.: Retrieval of Tropospheric $\mathrm{NO}_{2}$ from GOME Measurements, Adv. Space Res., 29(11), 1673-1683, 2002.

Richter, A. and Wagner, T.: Diffuser plate spectral structures and their influence on GOME slant columns, Technical note, available at: http://www.iup.uni-bremen.de/gome/data/diffuser 
gome.pdf, 2001.

Richter, A., Eyring, V., Burrows, J. P., Bovensmann, H., Lauer, A., Sierk, B., and Crutzen, P. J.: Satellite Measurements of $\mathrm{NO}_{2}$ from International Shipping Emissions, Geophys. Res. Lett., 31, L23110, doi:10.1029/2004GL020822, 2004.

Richter, A., Burrows, J. P., Nüß, H., Granier, C, and Niemeier, U.: Increase in tropospheric nitrogen dioxide over China observed from space, Nature, 437, 129-132, doi:10.1038/nature04092, 2005.

Rothman, L. S., Jacquemart, D., Barbe, A., Chris Benner, D., Birk, M., Brown, L. R., Carleer, M. R., Chackerian Jr., C., Chance, K., Coudert, L. H., Dana, V., Devi, V. M., Flaud, J.-M., Gamache, R. R., Goldman, A., Hartmann, J.-M., Jucks, K.W., Maki, A. G., Mandin, J.-Y., Massie, S. T., Orphal, J., Perrin, A., Rinsland, C. P., Smith, M. A. H., Tennyson, J., Tolchenov, R. N., Toth, R. A., Vander Auwera, J., Varanasi, P., and Wagner, G.: The HITRAN 2004 molecular spectroscopic database, J. Quant. Spectrosc. Radiat. Transfer, 96, 139-204, 2005.

Russell III, J. M., Solomon, S., Gordley, L. L., Remsberg, E. E., and Callis, L. B.: The variability of stratospheric and mesospheric $\mathrm{NO}_{2}$ in the polar winter night observed by LIMS, J. Geophys. Res., 89, 7267-7275, 1984.

Solomon, S., Schmeltekopf, A. L., and Sanders, R. W.: On the interpretation of zenith sky absorption measurements, J. Geophys. Res., 92, 8311-8319, 1987.

Solomon, S., Portmann, R.W., Sanders, R.W., Daniel, J.S., Madsen, W., Bartram, B., and Dutton, E.G.: On the role of nitrogen dioxide in the absorption of solar radiation, J. Geophys. Res., 104(D10), 12047-12058, 1999.
Valks, P., Pinardi, G., Richter, A., Lambert, J.-C., Hao, N., Loyola, D., Van Roozendael, M., and Emmadi, S.: Operational total and tropospheric $\mathrm{NO}_{2}$ column retrieval for GOME-2, Atmos. Meas. Tech. Discuss., 4, 1617-1676, doi:10.5194/amtd-4-1617-2011, 2011.

van $\operatorname{der}$ A, R. J., Peters, D. H. M. U., Eskes, H., Boersma, K. F., Van Roozendael, M., De Smedt, I., and Kelder, H. M.: Detection of the trend and seasonal variation in tropospheric $\mathrm{NO}_{2}$ over China, J. Geophys. Res., 111, D12317, doi:10.1029/2005JD006594, 2006.

Van Roozendael, M., De Maziere, M., Hermans, C., Simon, P. C., Pommereau, J., Goutail, F., Tie, X. X., Brasseur, G., and Granier, C.: Ground-based observations of stratospheric $\mathrm{NO}_{2}$ at high and midlatitudes in Europe after the Mount Pinatubo eruption, J. Geophys. Res., 102(D15), 19171-19176, doi:10.1029/97JD01098, 1997.

Vountas, M., Rozanov, V. V., and Burrows, J. P.: Ring effect: Impact of rotational Raman scattering on radiative transfer in earth's atmosphere, J. Quant. Spectrosc. Ra., 60, 943-961, 1998.

Vountas, M., Richter, A., Wittrock, F., and Burrows, J. P.: Inelastic scattering in ocean water and its impact on trace gas retrievals from satellite data, Atmos. Chem. Phys., 3, 1365-1375, doi:10.5194/acp-3-1365-2003, 2003.

Vrekoussis, M., Wittrock, F., Richter, A., and Burrows, J. P.: GOME-2 observations of oxygenated VOCs: what can we learn from the ratio glyoxal to formaldehyde on a global scale?, Atmos. Chem. Phys., 10, 10145-10160, doi:10.5194/acp-1010145-2010, 2010. 